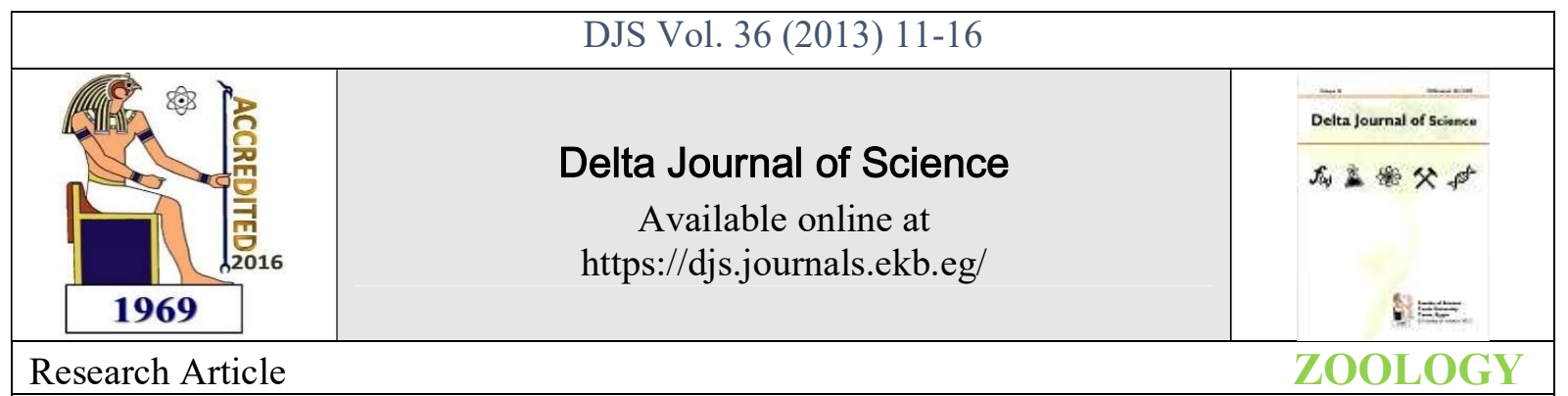

\title{
Hepatotoxicity, anti-oxidant defence dysfunction and oxidative stress of permethrin and cypermethrin in male albino rats.
}

\author{
Faten R. Abdel-Ghaffar a , Azza M. Mohamed ${ }^{\text {b }}$ \\ Ibrahim A. El-Elaimy ${ }^{a}$, and Mona A. Assar ${ }^{\text {a }}$
}

${ }^{a}$ Department of Zoology, Faculty of Science, Menoufia University, Shebin El-Kom, Egypt. ${ }^{b}$ Department of Biochemistry, National Research Center, Dokki, Egypt.

\begin{abstract}
Pyrethroids insectecides, permethrin(PM) and cypermethrin (CM) are used on a large scale in many agricultural protection programs and may cause hazards for animal and human health. The aim of the present study was to evaluate the hepatotoxicity of these pyrethroids on male albino rats in two foldes ; oxidative stress and antioxidant defence dysfunction. Rats received 1/60 LD50 of PM (20.83 mg/kg b. wt., orally/ day, for 30 days) and CM (8.33 mg/kg b. wt., orally/ day, for 30 days).Our results showed that serum hepatic function biomarkars, alanine aminotransferase (ALT) and aspartate aminotransferase (AST) enzymes, recorded a highly significant $(\mathrm{P}<0.001)$ elevation in both $\mathrm{PM}$ and $\mathrm{CM}$ treated groups. Various anti-oxidants; reduced glutathione, glutathione reductase, glutathione peroxidase, catalase and superoxide dismutase enzymes, recorded highly significant $(\mathrm{P}<0.001)$ reductions with both $\mathrm{PM}$ and $\mathrm{CM}$ treatment. On the other hand, oxidative stress markers; xanthine oxidase (XO), lipid peroxidation (LPO) and advanced oxidation protein products (AOPPs) elevated in treated animals with PM or CM. In general, it is clear from our data that, CM is more effective than PM. This may be expected with considering the presence of an alpha-cyno substituent in CM structure which can potentaite its toxicity.
\end{abstract}

Key words: Pyrethroids, Permethrin, Cypermethrin, Anti-oxidant defence, Oxidative stress.

*Corresponding author. E-mail address, Abdelghaffar_fr@yahoo.com Tel.0020482225215

\section{INTRODUCTION}

The early studies reported that pyrethroids are toxic to the central nervous system of both insects and mammals (Husain et al., 1996). Synthetic pyrethroid insecticides have been widely used in agriculture and domestic homes and account for approximately $25 \%$ of the worldwide insecticide market. They are derivatives of natural pyrethrins (Hossain et al., 2005). These insecticides have been divided into two types based on the absence (type I) or presence (type II) of an alphacyano substituent (Casida and Quistad, 1998; Nasuti et al., 2008).

Permethrin (PM), 3-Phenoxybenzyl-3-(2,2-dichlorovinyl)2,2-dimethyl-cyclopropane carboxylic acid, is one of type I pyrethroids used against pests on nuts, vegetables, fruits, cereal, cotton and to control termites in greenhouses and home gardens (Shafer et al., 2005 ; Kocaman and Topaktas, 2009). Recent studies reported that permethrin was highly toxic synthetic pyrethroid pesticide widely used in agriculture aquatic organisms and vector control programs (Vadhana et al., 2010; El-Demerdash, 2011).
Cypermethrin (CM), alpha-cyano-3-phenoxybenzyl ester of 2,2-dimethyl-3-(2,2-dichlorovinyl) cyclopropane carboxylic acid, is the most widely used Type II pyrethroid pesticide. It is used to control many pests and for the control of indoor (Carriquiriborde et al., 2007). Although it has low mammalian toxicity (Shashikumar and Rajini, 2010) it is highly hydrophobic compound and this suggests that its action in biological membranes might be related to association with integral proteins and with phospholipids (Michelangeli et al., 1990).

Oxidative damage primarily occurs through production of reactive oxygen species (ROS) and can damage lipids, proteins and DNA. Therefore, oxidative damage may contribute to loss of enzymatic activity and structural integrity of them and activate inflammatory processes (Ozyurt et al., 2004). Different studies have shown that many pesticides have the capacity to cause DNA damage (Kornuta et al., 1996; Shuka and Taneja, 2002; Bolognesi, 2003).

\section{Materials and methods}

\subsection{Chemicals}


Permethrin and Cypermethrin were obtained from EL-Help Company for pesticides production (Free Zone, New Damietta, Egypt). Reduced glutathione was obtained from Sigma Company, Japan. Hypoxanthine, CDNB (1-Chloro2, 4dinitrobenzene) were purchased from Alfa Aesar Company, Germany. All other reagents were of the highest purity available.

\subsection{Animals}

Male albino rats weighing $100-120 \mathrm{~g}$ from the animal house of National Research Center (Dokki, Egypt) were used. The animals were kept under standard housing conditions with a normal dark/light cycle. They were acclimatized to standard laboratory conditions for two weeks before the commencement of the experiment. They had free access to a rodent lab diet and water ad libitum.

\subsection{Experimental design}

The LD50 of both permethrin and cypermethrin were checked in our laboratory. To perform this study, twenty one adult male rats were used. Animals were randomly divided into 3 groups as follows:

Group (1): 7 rats received corn oil ( $2 \mathrm{ml} / \mathrm{kg} \mathrm{b}$. wt., orally/ day, for 30 days). They act as normal control.

Group (2): 7 rats received 1/60 LD50 of permethrin, dissolved in corn oil ( $20.83 \mathrm{mg} / \mathrm{kg} \mathrm{b}$. wt., orally/day, for 30 days).

Group (3): 7 rats received cypermethrin, dissolved in corn oil $(8.33 \mathrm{mg} / \mathrm{kg} \mathrm{b}$ wt., orally/ day, for 30 days $)$ dissolved in corn oil ( $2 \mathrm{ml} / \mathrm{kg}$ b.w.).

All animals were anaesthetized, after 24 hours from the last day of treatment, and blood samples were collected from the hepatic portal vein. Sera were separated by centrifugation of the blood samples at $3600 \mathrm{rpm}$ for $15 \mathrm{~min}$. liver samples were homogenized in saline solution $(1: 10 \mathrm{w} / \mathrm{v})$ and centrifuged at $3600 \mathrm{rpm}$ for $10 \mathrm{~min}$. All samples were kept in $-20 \mathrm{oC}$ for biochemical analysis.

\subsection{Methods}

The biochemical parameters were determined according to the corresponding authors as follows:

Serum alanine aminotransferase (ALT) and aspartate aminotransferase (AST) activities (Reitman and Frankel, 1957) were estimated. Liver reduced glutathione (GSH) level (Beutler and Kelley, 1963), glutathione reductase (GR) activity (Carlberg and Manervik, 1975), glutathione peroxidase (GPx) activity (Hafeman et al., 1974), catalase (CAT) activity (Goth, 1991), Superoxide dismutase (SOD) activity (Stewart and Bewley, 1980) and xanthine oxidase (XO) activity (Athar et al., 1996) were assayed. Also, serum advanced oxidation protein products (AOPP) (Witko-Sarsat et al., 1996) and liver lipid peroxidation as malonaldehyde (MDA) content, (Ruiz-Larrea et al., 1994) were estimated.

\section{Results}

Serum ALT and AST are indicators of hepatic function.

Table (1): Serum alanine aminotransferase (ALT) and aspartate aminotransferase (AST) activities in rats treated with permethrin and cypermethrin for 30 days.

\begin{tabular}{clll}
\hline Parameters & Control & Permethrin & Cypermethrin \\
& & & \\
\hline \multirow{2}{*}{ ALT } & $53.50 \pm 450$ & $\begin{array}{l}64.00 \pm 0.583^{\circ} \\
(19.6 \%)\end{array}$ & $\begin{array}{l}74.00 \pm 0.513^{\circ} \\
(38.3 \%)\end{array}$ \\
& & & \\
AST & $99.20 \pm 0.451$ & $121.00 \pm 0.513^{\circ}$ & $135.68 \pm 0.4920^{\circ}$ \\
& & $(21.9 \%)$ & $(36.8 \%)$ \\
\hline
\end{tabular}

Values are expressed as means $\pm S E,(n=7)$. (c) $P<0.001$ versus control group. ALI\& AST activities is expressed as (U/L).
Compared to the control group, $\mathrm{PM}$ and $\mathrm{CM}$ treated groups recorded highly significant elevations $(\mathrm{P}<0.001)$ in serum ALT $(19.6 \%),(38.3 \%)$ and AST $(21.9 \%),(36.8 \%)$ to both pyrethroids respectively, after 30 days of treatment, in comparison with their control groups (Table 1).

There was a highly significant diminution $(\mathrm{P}<0.001)$ in $\mathrm{GSH}$ (16.3\% and $29.1 \%)$, GR (10.8 \% and $13.7 \%)$ and GPx (18.3\% and $26.7 \%$ ) levels with PM and CM treatment, respectively, compared to their control values (Table 2).

Table (2): reduced glutathione (GSH), glutathione peroxidase (GPx) and glutathione reductase (GR) in rats treated with permethrin and cypermethrin for 30 days.

\begin{tabular}{clll}
\hline Parameters & Control & Permethrin & Cyperrmethrin \\
\hline GSH & $59.00 \pm 0.550$ & $\begin{array}{l}49.42 \pm 0.513^{\circ} \\
(-16.3 \%)\end{array}$ & $\begin{array}{l}40.40 \pm 0.490^{\circ} \\
(-29.1 \%)\end{array}$ \\
& & $86.40 \pm 0.680^{\circ}$ & $83.60 \pm 0.580^{\circ}$ \\
GR & $96.90 \pm 0.490$ & $(-10.8 \%)$ & $(-13.7 \%)$ \\
& & $29.00 \pm 0.510^{\circ}$ & $26.01 \pm 0.713^{\circ}$ \\
GPx & $35.50 \pm 0.371$ & $(-18.3 \%)$ & $(-26.7 \%)$
\end{tabular}

Values are expressed as means $\pm S E_{\ldots,}(n=7)$. (c) $P<0.001$ versus control group.

GSH level was expressed as ( $\mathrm{mg} / \mathrm{g}$ tissue)

GPx activity is expressed as (umoles of GSH oxidized $/ \mathrm{min} / \mathrm{mg}$ tissue).

GR activity is expressed as (umoles of NADPH oxidized $/ \mathrm{min} / \mathrm{mg}$ tissue)

On the same manner, CAT and SOD activities showed a highly significant decrease in PM and CM treated groups, as submitted in (Table 3).

The percentage changes for CAT enzyme were $17.5 \%$ and $21.0 \%$ for PM and CM treated groups, while for SOD it was $11.5 \%$ for PM and $17.5 \%$ for

$\mathrm{CM}$. On contrary, the oxidative stress enzyme XO showed a significant increase $(\mathrm{P}<0.05)$ in its activity in $\mathrm{PM}$ and $\mathrm{CM}$ treated groups with percentages, $17.7 \%$ and $26.2 \%$ respectively, versus control group (Table 3).

Table (3): Liver activities of catalase (CAT), superoxide dismutase (SOD) and xanthine oxidase $(\mathrm{X} 0$ ) in rats treated with permethrin and cypermethrin for 30 days.

\begin{tabular}{llll}
\hline Parameters & Control & Permethrin & Cypermethrin
\end{tabular}

\begin{tabular}{|c|c|c|c|}
\hline CAT & $338.00 \pm 0.450$ & $\begin{array}{c}279.00 \pm 0.492^{\circ} \\
(-17.5 \%)\end{array}$ & $\begin{array}{c}267.00 \pm 0.580 \mathrm{c} \\
(-21.0 \%)\end{array}$ \\
\hline SOD & $96.80 \pm 0.630$ & $\begin{array}{c}85.71 \pm 0.580 c \\
(-11.5 \%)\end{array}$ & $\begin{array}{c}78.22 \pm 0.370^{\circ} \\
(-17.5 \%)\end{array}$ \\
\hline X0 & $0.355 \pm 0.140$ & $\begin{array}{c}0.418 \pm 0.190 \mathrm{~s} \\
(17.7 \%)\end{array}$ & $\begin{array}{c}0.448 \pm 0.370 \mathrm{a} \\
(26.2 \%)\end{array}$ \\
\hline \multicolumn{4}{|c|}{$\begin{array}{l}\text { Values are expressed as means } \pm \mathrm{SE} \text {, ( } \mathrm{n}=7) \text {. } \\
\text { CAT activity is expressed as }(\mathrm{KU} / \mathrm{L}) \text {. } \\
\text { SOD activity is expressed as \% inhibition. } \\
\mathrm{X} 0 \text { activity is expressed as ( } \mu \mathrm{g} \text { of uric acid formed/min/gm tissue). } \\
\text { (a)P<0.05 and (c) } \mathrm{P}<0.001 \text { versus control group. }\end{array}$} \\
\hline
\end{tabular}


Changes in AOPP and LPO levels, were recorded in (Table 4). There was a marked significant elevation $(\mathrm{P}<0.001)$ in serum

\section{AOPP levels in PM and CM groups with percentage changes}

of $28.7 \%$ and $29.4 \%$, over normal values, respectively. On the same line, LPO, as malonialdehyde (MDA), level showed a highly significant increase $(\mathrm{P}<0.001)$ in PM $(26.5 \%)$ and $\mathrm{CM}$ $(29.8 \%)$ groups when compared to control animals.

\section{Table (4): Liver adranced oxidation protein products (AOPPs) and lipid peroxidation (LP0) levels in rats treated with permethrin and cypermethrin after 30 dars.}

\begin{tabular}{clll} 
parameters & Control & Permethrin & Cyperrmethrin \\
& & & \\
\hline A0PPs & $23.25 \pm 0.450$ & $29.92 \pm 0.373 \mathrm{c}$ & $30.08 \pm 0.370 \mathrm{c}$ \\
& & $(28.7 \%)$ & $(29.4 \%)$ \\
& & & \\
LPO & $42.60 \pm 0.580$ & $53.90 \pm 0.510 \mathrm{c}$ & $55.31 \pm 0.580 \mathrm{c}$ \\
& & $(26.5 \%)$ & $(29.8 \%)$ \\
& & & \\
\hline
\end{tabular}

Values are expressed as means $\pm S E$., $(\mathrm{n}=7)$. (c) $\mathrm{P}<0.001$ versul contitol group. AOPPs activity is expressed as (umol L of chloramine-Tequivalents). LPO level is expressed as (nmol.MDA formed hir gm tissue).

\section{Discussion}

Serum ALT and AST enzymes are used as indices of liver functions. In the present work, they increased significantly with permethrin and cypermethrin treatment. This elevation could be attributed to hepatic cells dysfunction induced as a result of oxidative stress and / or the damage in structural integrity of the liver, as these compounds are released into the circulation after cellular damage (Barzilai and Yamamoto, 2004). These observations matched with finding of CM toxicity in rabbits (Yousef et al., 2003), in poultry birds (Kumar et al. 2010), in rats (Sankar et al., 2012), and in albino mice (Ince et al., 2012). Similarly, Akbar et al. (2012) found that, permethrin and fenvalarate exposure altered the activities of anti-oxidant enzymes leading to oxidative stress in cells.

Induction of oxidative stress is one of the main mechanisms of action of many insecticides. In most cases, the abnormal generation of reactive oxygen species (ROS), which can result in significant damage to cell structure, is considered an important signal of oxidative damage (Barzilai and Yamamoto, 2004). GSH plays a crucial role in both scavenging ROS and the detoxification of xenobiotics (Haque et al., 2003). In addition, it is known to act as a substrate for glutathione peroxidase and glutathione-S-transferase enzymes (Lin et al., 2008). In the current study, there was a significant reduction in GSH level with both PM and CM treatment. It was suggested that significant decreases in GSH levels may be due to either inhibition of GSH synthesis and / or increased utilization of it for detoxification of toxicants or their free radicals (Singh et al., 2001; Raina et al., 2009; Ince et al., 2012). El-Demerdash (2011) reported a reduction in GSH content of rats exposed to a mixture of synthetic pyrethroids and organophosphate insecticides. Moreover, the decreased GSH level may be as a result of its consumption for detoxification of the products resulted from the metabolism of both used pyrethroids.

In general, GPx is involved in protection of cytosol and plasma membrane from lipid peroxidation, whereas this enzyme transforms hydroperoxides, produced at the membrane level as a result of oxidative damage, into less reactive species (Gabbianelli et al., 2004).

Our data showed that GPx exhibited a significant diminution with PM and CM treatment. Similar results have been recorded in rats treated with permethrin (Gabbianelli et al., 2004) and others exposed to CM (Hussien et al., 2011). Those authors suggested that this reduction in GPx may be due to reduced level of GSH, which acts as a substrate for this enzyme and / or as a result of its consumption for reduction of pesticide-induced lipid peroxidation. On the other hand, GR which is an important enzyme for maintaining the intracellular level of GSH. Kumaran et al. (2004) showed a significant reduction in PM and $\mathrm{CM}$ treated animals. Olgun and Misra (2006) found that the pesticides malathion or (lindane+permethrin) mixture inhibited GSH-peroxidase and GSH-reductase activities. They noted that mixture of these pesticides have oxidative responses greater than those of single ones. This reduction may be contributed to the direct effect of the pyrethroids and their metabolites on this enzyme synthesis or due to its exhausting to compensate the reduction of intracellular GSH (El-Demerdash, 2011; Akbar et al., 2012).

superoxide radical (O2--) the parental form of intracellular ROS, is a very reactive molecule, but it can be converted to $\mathrm{H} 2 \mathrm{O} 2$ by superoxide dismutase (SOD), and then to water by catalase (CAT) enzyme (Pi et al., 2010). In the present study, a significant reduction of SOD and CAT activities in PM and $\mathrm{CM}$ treated animals was produced. The decline of SOD activity was supported by decrease in brain SOD activity in rats exposed to pyrethroids (Sinha et al., 2006). On the level of erythrocytes, lambada-cyhalothrin, recorded a similar observation for SOD (El-Demerdash, 2007) whereas activities of anti-oxidant enzymes were decreased in rats. These results were in agreement with Raina et al. (2009) who reported significant decreases in SOD activities in rats treated with CM. Tisch et al. (2002) reported that the treatment with a high dose of PM induced a decrease of erythrocyte CAT activity. The association of these findings has been also reported (Akbar et al., 2012; Sankar et al., 2012).

In earlier study, it is well documented that pyrethroids indirectly generates various radicals as superoxide radical, nitrogen species, such as nitric oxide and hydroxyl radical thus causing damage consistent with oxidative stress (Kale et al., 1999). These radicals may attack the cell membrane leading to oxidation of lipids of cellular membrane. One of the primary events in oxidative cellular damage can be assessed by measurement of malondialdehyde (MDA), a breakdown product of lipid peroxides (Hu et al., 2009). Its concentration in the liver tissues was used as an indicator of lipid peroxidation and oxidative stress (Taha et al. 2010). Our results showed a significant elevation in MDA with PM and $\mathrm{CM}$ treated groups. The results were in agreement with the findings of Prasanthi et al. (2005) and El-Demerdash (2007); Akbar et al. (2012) who reported that oxidative damage induced by pyrethroids may be due to their lipophilicity, whereby they could penetrate the cell membrane easily and lead to destabilization and disintegration of it by induced lipid peroxidation. 
Advanced oxidation protein products (AOPPs) assay is considered as a marker that provides information on the degree of oxidative damage to proteins (Kayali et al., 2007). The accumulation of oxidized protein reflects not only the rate of protein oxidation but also the rate of oxidized protein degradation (Beal, 2002; Stadtman, 2004). The Present work showed significant elevated AOPPs in PM and CM treated animals. This elevation of AOPPs is due to protein damaged by pyrethroids-induced oxidative stress reactions. The conformational changes that result from these complex reactions lead to the decrease or loss of protein biological function as well as its AOPPs accumulation (Khan and Sultana, 2004). In the other side, this induced oxidative stress is correlated with elevated xanthine oxidase activity, which is an oxidized enzyme for purines, protein and amino acid catabolism. Xanthine oxidase enzyme plays an important role in oxidative stress whereas it reduces molecular oxygen, leading to the formation of both superoxide and hydrogen peroxide (Wassmann et al., 2004)

Therefore, from the present study we can conclude that the oxidative stress is the possible mechanism of permethrin and cypermethrin intoxication. On the other hand, cypermethrin was stronger as an inducer for oxidative stress and antioxidant defence dysfunction than permethrin. It has been suggested that cypermethrin is highly hydrophobic and this suggests that its action on biological membranes might be more effective with integral proteins and phospholipids. Moreover, this may be expected with considering the presence of an alpha-cyano substiteunt in cypermethrin structure which can potentiate its toxicity.

\section{References}

Akbar SMD, Sharma HC, Jayalakshmi S, Ksreeramulu K, (2012). Effect of pyrethroids, permethrin and fenvalarate, on the oxidative stress of Helicoverpa armigera. World J. Sci. Technol. 2(1): 01-05.

Athar M, Sharma SD, Iqbal M, Sultana S, Pandaya KB, Tripathi IP, (1996). Coordination of copper polyamines complex with immidiozoles potentiates its superoxide dismutase mimicking activity and abolishes its interactions with albumin. Biochem. Mol. Biol. Int., 39: 813-821.

Barzilai A, Yamamoto K I, (2004). DNA damage responses to oxidative stress. DNA Repair. 3: 1109-1115.

Beal M F, (2002). Oxidatively modified proteins in aging and disease. Free. Radic. Biol. Med. 32: 797-803.

Beutler E, Kelly B M, (1963). The effect of sodium nitrite on red cell GSH. Experimentia. 19: 96-103.

Casida JE, Quistad GB, (1998). Golden age of insecticide research: past, present, or future? Annu. Rev. Entomol. 43: 116.

Carlberg I, Mannervik B, (1975). Glutathione level in rat brain. J. Biol. Chem. 250: 4480-4575.

Carriquiriborde P, Diaz J, Mugni H, Bonetto C, Ronco AE, (2007). Impact of cypermethrin on stream fish populations under field-use in biotech-soybean production. Chemosphere 68: 613-621.

El-Demerdash FM, (2007). Lambda-cyhalothrin-induced changes in oxidative stress biomarkers in rabbit erythrocytes and alleviation effect of some antioxidants. Toxicol. In Vitro. 21: 392-397.
El-Demerdash FM, (2011). Lipid peroxidation, oxidative stress and acetylcholinesterase in rat brain exposed to organophosphate and pyrethroid insecticides. Food Chem. Toxicol. 49: 1346-1352.

Gabbianelli R, Falcioni G, Nasuti C, Cantalamessa F, (2002). Cypermethrin-induced plasma membrane perturbation on erythrocytes from rats: reduction of fluidity in the hydrophobic core and in glutathione peroxidase activity. Toxicol. 175: 91-101.

Gabbianelli R, Nasuti C, Falcioni G, Cantalamessa F, (2004). Lymphocyte DNA damage in rats exposed to pyrethroids: effect of supplementation with Vitamins E and C. Toxicol. 203: $17-26$

Gallan PM, Carrascosa A, Gussinye M, Dominguez C, (2003). Biomarkers of diabetes-associated oxidative stress and antioxidant status in young diabetic patients with or without subclinical complication. Free Radic. Biol. Med. 34: 15631574.

Goth L, (1991). A simple method for determination of serum catalase activity, and revision of reference range. Clin. Chim. Acta. 196:143-152.

Hafeman DG, Sunde RA, Hoekstra WG,(1974). Effect of dietary selenium on erythrocyte and liver glutathione peroxidase in the rat. J. Nutr. 104: 580-587.

Haque R, Bin-Hafeez B, Parvez S, Pandey S, Sayeed I, Ali M, Raisuddin S, (2003). Aqueous extract of walnut (Juglans regia $L$.), protects mice against cyclophosphamide-induced biochemical toxicity. Hum. Exp. Toxicol. 22: 473-80.

Hossain M M, Suzukia T, Sato I, Tadashi T, Suzukib K, Kobayashi H, (2005). Neuromechanical effects of pyrethroids, allethrin, cyhalothrin and deltamethrin on the cholinergic processes in rat brain. Life Sci. 77: 795-807.

Hu F, Li L, Wang C, Zhang Q, Zhang X, Zhao M, (2009). Enantioselective induction of oxidative stress by permethrin in rat adrenal pheochromocytoma (Pc12) cells. Environ. Toxicol. Chem. 29(3): 683-690.

Husain R, Husain R, Adhami VM, Seth PK, (1996). Behavioral, neurochemical and neuromorphological effects of deltamethrin in adult rats. J. Toxicol. Envioron. Health. 48 (5): 515-526.

Hussien HM, Abdou HM, Yousef MI, (2011). Cypermethrin induced damage in genomic DNA and histopathological changes in brain and haematotoxicity in rats: The protective effect of sesame oil. Brain Res. Bulletin. 11( 9) : In press.

Ince S, Kucukkurt I, Demirel HH, Turkmen R, Sever E (2012). Thymoquinone attenuates cypermethrin-induced oxidative stress in Swiss albino mice. Pesticide biochem. Physiol. 104(3): 229-235.

Kale M, Rathore N, John S, Bhatnagar D, (1999). Lipid peroxidative damage on pyrethroid exposure and alterations in antioxidant status in rat erythrocyte: a possible involvement of reactive oxygen species. Toxicol. Lett. 105: 197-205. 
Faten R. Abdel-Ghaffar. Hepatotoxicity, anti-oxidant defence dysfunction and oxidative stress

Kayali R, Akatay U, Tekeli F, (2007). Male rats exhibit higher oxidative protein damage than females of the same chronological age. Mech. Ageing Devel. 128: 365-369.

Khan N, Sultana S, (2004). Induction of renal oxidative stress and cell proliferation response by ferric nitriliotriacetate (FeNTA): diminution by soy isoflavine. Chemico-Biolog. Interact. 149: 23-35.

Kocaman AY, Topaktas M, (2009). The In Vitro Genotoxic Effects of a Commercial Formulation of a-Cypermethrin in human peripheral Blood Lymphocytes. Environ. Molec. Mutagen. 50:27-36.

Kornuta N, Bagley E, Nedopitanskaya N, (1996). Genotoxic effects of pesticides. J. Environ. Pathol. Toxicol. Oncol. 15 $(2-4): 75-78$

Kumar MR, Reddy GA, Anjaneyulu Y, Reddy GD, (2010). Oxidative stress induced by Lead and Antioxidant potential of certain Adaptogens in poultry. Toxicol. Intl. 17(2): 45- 48.

Kumaran S, Savitha S, Anusuya DM, Panneerselvam C, (2004). L-carnitine and DL-alpha-lipoic acid reverse the agerelated deficit in glutathione redox state in skeletal muscle and heart tissues. Mech. Ageing Dev. 125(7): 507-512.

Lin HM, Tseng HC, Wang CJ, Lin JJ, Lo CW, Chou FP, (2008). Hepatoprotective effects of Solanum nigrum Linn. extract against CCL4-induced oxidative damage in rats. Chemico-Biologica. Interact. 171: 283-293.

Michelangeli F, Robson MJ, East JM, Lee AG, (1990). The conformation of pyrethroids bound to lipid bilayers. Biochim. Biophys. Acta. 1028: 49-57.

Nasuti C, Cantalamessa F, Falcioni G, Gabbianelli R, (2003). Different effects of Type I and Type II pyrethroids on erythrocyte plasma membrane properties and enzymatic activity in rats. Toxicol. 191: 233-244.

Nasuti C, Falcioni M L, Nwankwo I E, Cantalamessa F, Gabbianelli R, (2008). Effect of permethrin plus antioxidants on locomotor activity and striatum in adolescent rats. Toxicol. 251: 45-50

Olgun S, Misra HP, (2006). Pesticides induced oxidative stress in thymocytes. Molec. Cellu. Biochem. 290: 137-144.

Ozyurt H, Sogut S, Yildirim Z, Kart L, Iraz M, Armutcu F, Ismail T, Ozen S, Uzun A, Akyol O, (2004). Inhibitory effect of caffeic acid phenethyl ester on bleomycine-induced lung fibrosis in rats. Clin. Chim. Acta. 339: 65-75.

Pandey S, Sayeed I, Ali M, Raisuddin S, (2003). Aqueous extract of walnut (Juglans regia L.), protects mice against cyclophosphamide-induced biochemical toxicity. Hum. Exp. Toxicol. 22: 473-480.

Pi J, Zhang Q, Fu JG, Woods CG, Hou Y, Corkey BE, Collins S, Andersen ME, (2010). ROS signaling, oxidative stress and Nrf2 in pancreatic beta-cell function. Toxicol. Appl. Pharmacol. 244: 77-83.

Prasanthi K, Muralidhara, Rajini PS, (2005). Morphological and biochemical perturbations in rat erythrocytes following in vitro exposure to Fenvalerate and its metabolite. Toxicol. In Vitro. 19: 449-456.
Raina R, Verma PK, Pankaj NK, Prawez S, (2009). Induction of oxidative stress and lipid peroxidation in rats chronically exposed to cypermethrin through dermal application. J. Vet. Sci. 10(3): 257-259.

Reitman S, Frankel S, (1957). A colorimetric method for the determination of serum glutamic oxalacetic and glutamic pyruvic transaminases, Am. J. Clin. Pathol. 28:56-63.

Ruiz-Larrea MB, Leal AM, Liza M, Lacort M, De- Groot H, (1994). Antioxidant effects of estradiol and 2hydroxyestradiol on iron-induced lipid peroxidation of rat liver microsomes. Steroids, 59: 383-388.

Sankar P, Telang AG, Manimaran A, (2012). Protective effect of curcumin on cypermethrin-induced oxidative stress in Wistar rats. Experimental and Toxicol. Pathol. 64: 487493.

Shafer TJ, Meyer DA, Crofton KM, (2005).Developmental neurotoxicity of pyrethroid insecticides: critical review and future research needs. Environ. Health Perspect. 113(2):123136

Shashikumar S, Rajini PS, (2010). Cypermethrin-induced alterations in vital physiological parameters and oxidative balance in Caenorhabditis elegans, Pesticide Biochem. Physiol. 97: 235-242.

Shuka Y, Taneja P, (2002). Mutagenic potential of cypermethrin in mouse dominant lethal assay. J. Environ. Pathol. Toxicol. Oncol. 21 (3): 259-265.

Singh SN, Vats P, Kumria MM, Ranganathan S, Shyam R, Arora MP, Jain CL, Sridharan K, (2001). Effect of high altitude $(7,620 \mathrm{~m})$ exposure on glutathione and related metabolism in rats. Eur. J. Appl. Physiol. 84: 233-237.

Sinha C, Seth K, Islam F, Kumar R, Shukla CS, Mathur N, Srivastava Agrawal K, (2006). Behavioral and neurochemical effects induced by pyrethroid-based mosquito repellent exposure in rat offsprings during prenatal and early postnatal period. Neurotoxicol. Teratol. 28: 472-481.

Stadtman R, (2004). Role of oxidant species in aging. Curr. Med. Chem. 11:1105-1112.

Taha MM, Abdul AB, Abdullah R, Ibrahim TAA, Abdelwahab SI, Mohan S, (2010). Potential chemoprevention of diethyl nitrosamine-initiated and 2-acetylaminofluorenepromoted hepatocarcinogenesis by zerumbone from the rhizomes of the subtropical ginger (Zingiber zerumbet). Chemico-Biologic. Interact. 186: 295-305.

Tisch M, Schmezer P, Faulde M, Groh A, Maiser H, (2002). Gentoxicity studies on permethrin, DEET and diazinon in primary human nasal mucosal cells. Eur. Arch. Otorhino laryngol. 259(3): 150-153.

Vadhana MS, Nasuti C, Gabianelli R, (2010). Purine bases oxidation and repair following permethrin insecticide treatment in rat heart cells. Cardiovas. Toxicol. 10: 199-207.

Wang XZ, Liu SS, Sun Y, Wu JY, Zhou YL, Zhang JH, (2009). Beta-cypermethrin impairs reproductive function in male mice by inducing oxidative stress. Theriogenol. 72: 599611 
Wassmann S, Wassmann K, Nickenig G, (2004). Modulation of oxidant and anti-oxidant enzyme expression and function in vascular cells. Am. Heart Assoc. Hypertens. 44: 381-386.

Witko-Sarsat V, Friedlander VM, Capéillere C, Nguyen-khoa AT, Zingraff J, Jungers P, Deschamps-Latscha B, (1996). Advanced oxidation protein products as a novel marker of oxidative stress in uremia. Kidney Interact. 49:1304-1313.

Yousef M I, EL Demerdash FM, Kamei KI, Salhen KS, (2003). Changes in some hematological and biochemical indices of rabbits induced by isoflavones and cypermethrin. Toxicol. 189: 223-234.

$$
\begin{aligned}
& \text { الملخص العربي } \\
& \text { التسمم الكبدي,الخلل فى الدفاع ضد الأكسدة والضغط التأكسدي للبيرميثرين } \\
& \text { والسييرميشرين في ذكور الجرذان المهقاء } \\
& \text { *فاتن رشدي عبد الغفار * * عزة مصطفى محمد إبراهيم عبد الحميد }
\end{aligned}
$$

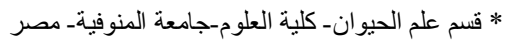

$$
\begin{aligned}
& \text { **قنم الكيمياء الحيويةـ المركز القومي للبحوث-مصر } \\
& \text { البيروثرويدات , مبيدات حشرية , مثل بالبيرميثرين (PM) والسيبريز ميثرين }
\end{aligned}
$$

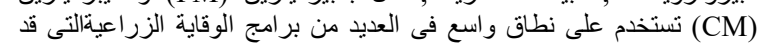

$$
\begin{aligned}
& \text { تسبب مخاطر لصحة كل من الحيو أن و والانسان. }
\end{aligned}
$$

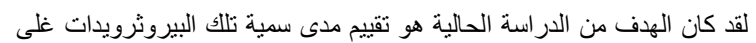

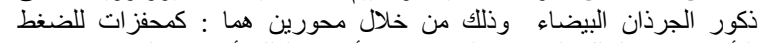

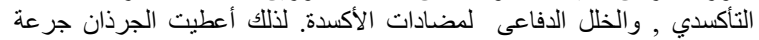

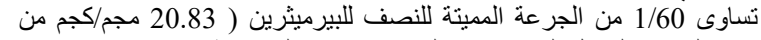

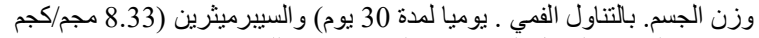

$$
\begin{aligned}
& \text { من وزن الجسم. بالتناول الفمي. يو يوميا لمدة } 30 \text { يوم) للجرذان. }
\end{aligned}
$$

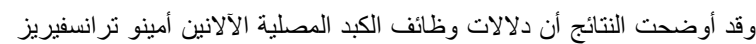

$$
\begin{aligned}
& \text { و أسبرتيت أمينو ترانسفيريز (ALT) }
\end{aligned}
$$

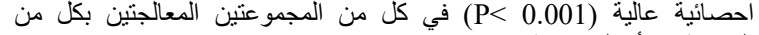

$$
\begin{aligned}
& \text { البيرميثرين أو السيبرميثرين . } \\
& \text { البيرميثرين أو السييرميثرين }
\end{aligned}
$$

